\title{
Methionine and lysine supplementation of groundnut meal in experimental diets for laying hens
}

\author{
By J. DAVIDSON AND A. W. BOYNE \\ Rowett Research Institute, Bucksburn, Aberdeen \\ (Received 22 fanuary, 1962-Revised I2 March I962)
}

In order to make the best use of the various protein concentrates available for supplementing laying diets it is necessary to know their relative values for promoting egg production when given as supplements to a basal mixture of cereals. The reason or reasons for one concentrate being inferior to another can then be considered and economic ways tested to correct any deficiency. Experimental studies on the relative values should be carried out with diets containing a critical amount of total protein, so that differences in quality of concentrate protein are not obscured by an excess. It has already been established in work with hens housed intensively (Carpenter, Duckworth \& Ellinger, 1954) that provided there is an excess of crude protein allvegetable rations composed of a cereal mixture, wheat offals and groundnut meal can allow as good egg production as conventional rations containing animal-protein supplements such as white-fish meal. Diets containing $14 \%$ total protein, with I I-10\% from cereal sources and $3-4 \%$ from protein supplement, gave rise to similar egg productions irrespective of whether the supplement was vegetable protein from groundnut meal or animal protein from white-fish meal. However, when the total protein content of the diet was reduced to I I $\%$, with $8 \%$ from cereal sources and $3 \%$ from protein supplement, the protein of white-fish meal proved superior to groundnut-meal protein. The diet containing $11 \%$ protein with $3 \%$ from white-fish meal was as productive as the diets containing a total of $\mathrm{I}_{4} \%$ protein with $4 \%$ protein from either white-fish meal or groundnut meal.

A dietary protein content of $\mathrm{II}-\mathrm{I} 2 \%$ is probably critical for laying hens on the type of diet that is based on a mixture of barley, oats, wheat and wheat offals, and which has a metabolizable energy (ME) content of about $2.5 \mathrm{Mcal} / \mathrm{kg}$. The crude-protein:ME ratio in $\mathrm{g} / \mathrm{Mcal}$ of about $44-48$ is somewhat lower than the 52 calculated by us for diets recommended by the (US) National Research Council: Committee on Animal Nutrition ( 1960 ). The NRC recommend $15 \%$ for diets that are usually based on maize and soya-bean meal and contain about $2.9 \mathrm{Mcal} \mathrm{ME} / \mathrm{kg}$.

In the work here described on the quality of protein in supplements to laying diets, the percentage of protein in the test diet has been restricted to ro or I I \%. In an earlier report Carpenter (1954) has suggested that with diets that are critical in protein content egg production is higher with white-fish meal than with groundnut meal as the supplement because of a more favourable amino acid balance in the white-fish meal. The aim of the study described here was to provide further information on the relative values of white-fish meal and groundnut meal as supplements to laying diets and, on the 
assumption that amino acid balance is the main cause of any difference in supplementary values, to find out which amino acids improved the groundnut meal.

The code letters of the samples in this paper do not refer to those distributed to laboratories participating in the Agricultural Research Council collaborative trial on protein quality mentioned by Duckworth, Woodham \& McDonald (I96I).

\section{Amino acid requirements}

Less is known about amino acid requirements of the laying hen than about the requirements of the starting chick. In fact, in 1956 , when our studies began, the NRC had listed only lysine, methionine, cystine and tryptophan; in I 960 they added leucine, isoleucine and threonine ((USA) National Research Council: Committee on Animal Nutrition, 1954, Ig60).

Table I. Expts 1-3. Calculated composition of laying diets with respect to important amino acids

\begin{tabular}{|c|c|c|c|c|c|c|c|c|c|c|}
\hline & \multirow{2}{*}{\multicolumn{2}{|c|}{$\begin{array}{l}\text { Requirement } \\
\text { according } \\
\text { to NRC** } \\
\text { expressed as }\end{array}$}} & \multicolumn{4}{|c|}{ White-fish meal diet } & \multicolumn{4}{|c|}{ Groundnut diet } \\
\hline & & & \multirow[b]{2}{*}{$\begin{array}{l}\text { Basal } \\
\text { diet } \\
(\%)\end{array}$} & \multirow[b]{2}{*}{$\begin{array}{c}\text { Supple- } \\
\text { ment } \\
(\%)\end{array}$} & \multicolumn{2}{|c|}{ Total } & \multirow[b]{2}{*}{$\begin{array}{l}\text { Basal } \\
\text { diet } \\
(\%)\end{array}$} & \multirow[b]{2}{*}{$\begin{array}{c}\text { Supple- } \\
\text { ment } \\
(\%)\end{array}$} & \multicolumn{2}{|c|}{ Total } \\
\hline & $\begin{array}{c}\% \\
\text { of diet }\end{array}$ & $\begin{array}{l}\% \text { of } \\
\text { protein }\end{array}$ & & & $(\%)$ & $\begin{array}{c}\% \text { of } \\
\text { protein }\end{array}$ & & & $\%$ & $\begin{array}{l}\% \text { of } \\
\text { protein }\end{array}$ \\
\hline $\begin{array}{l}\text { Protein } \\
\text { Lysine }\end{array}$ & $\begin{array}{l}15 \\
0.50\end{array}$ & $\overline{3.3}$ & $\begin{array}{l}7.5 \\
0.26\end{array}$ & $\begin{array}{l}2 \cdot 5 \\
0.23\end{array}$ & $\begin{array}{l}\text { I0 } \\
0.49\end{array}$ & $\overline{4.9}$ & $\begin{array}{l}7 \cdot 5 \\
0 \cdot 26\end{array}$ & $\begin{array}{l}2.5 \\
0.08\end{array}$ & $\begin{array}{l}\text { 10 } \\
0.34\end{array}$ & $\overline{3.4}$ \\
\hline Methionine + cystine & 0.53 & 3.5 & 0.25 & 0.10 & 0.35 & 3.5 & 0.25 & 0.07 & 0.32 & $3 \cdot 2$ \\
\hline Tryptophan & 0.15 & $1 \cdot 0$ & 0.08 & 0.03 & O.II & $I \cdot I$ & 0.08 & 0.03 & O.II & $\mathrm{I} \cdot \mathrm{I}$ \\
\hline
\end{tabular}

* (USA) National Research Council: Committee on Animal Nutrition (1954, I960).

Values for lysine, methionine plus cystine, and tryptophan in typical diets used in our experiments were computed from tables compiled by de Man \& Zwiep (1955). These values are given in Table I, along with the requirements recommended by the NRC in 1954 and 1960.

From Table I it seems probable that methionine will be limiting in diets supplemented with groundnut meal and that lysine may also be deficient, especially if quality has been impaired during processing. These were the amino acids added to groundnut diets in our study.

\section{EXPERIMENTAL AND RESULTS}

\section{Preliminary studies}

A study carried out in 1954 (Carpenter, 1954) with groups of birds in indoor pens showed that fortification of a groundnut meal with DL-methionine may improve its value as a supplementary protein almost up to that of white-fish meal. A repetition of this work on a second groundnut meal again in indoor pens did not confirm this finding, egg production being the same whether the diet contained white-fish meal or groundnut meal. 
In the preliminary experiment of our series during $1956-7$ with birds housed in individual cages of a laying battery, fortification of a third groundnut meal $\left(\mathrm{GNX}_{3}\right)$ with various levels of DL-methionine was again without effect on egg production. The diets contained $8 \%$ protein from the basal cereal mixture and $3 \%$ from the supplement. Results showed that mean production was maintained at a level of around four eggs/week over the 24 experimental weeks, with an efficiency of feed conversion (egg weight/feed weight) of 0.24 , a figure comparing favourably with the values of 0.22 and 0.23 obtained in previous studies when white-fish meal was the supplement (Carpenter, 1954; Carpenter et al. 1954). It was subsequently found that the gross protein value (GPV) (Duckworth et al. I96I) of this particular meal was as high as 54 and so it may have been particularly well processed. These findings suggested that, when used as supplements for laying hens, only those groundnut meals in which the protein had been altered in some way during processing could be improved by addition of methionine. Thus in the years $1957-60$, experiments were carried out with a Burmese groundnut meal $\left(\mathrm{GNX}_{4}\right)$ which was judged to be of poor quality, having a GPV of 36 .

\section{General procedure in Expts $\mathrm{I}, 2$ and 3}

About $25^{\circ}$ White Leghorn $\times$ Rhode Island Red pullets hatched in April were reared for to weeks on deep litter and then on range with commercial rearing diets until they reached point of lay at about 22 weeks of age. About 200 were then selected and placed at random in the individual cages of a three-tier commercial laying battery constructed from galvanized iron wire and sheet. During the succeeding 6-9 weeks the protein in a preliminary diet, which was similar to the groundnut control diet to be tested, was reduced stepwise to below I2 \%, and egg production of each bird was recorded. On the basis of these preliminary records, 168 birds in the first experiment and 134 in the other two were selected and randomized to treatments. Egg production was recorded over 24 or 26 weeks. Birds were culled if records showed that they had not laid eggs for 3 successive weeks. Each bird had access to dry mash and water at all times. Artificial lighting gave i $3 \mathrm{~h}$ light each day.

The diets used in Expt $\mathrm{I}$ are shown in Table 2; those used in Expts 2 and 3 were similar. The diets provided $6 \frac{1}{2} \%$ protein from the basal mix and $2 \frac{1}{2} \%$ protein from the test protein; they contained oat feed to make the crude fibre content up to $6 \%$ and bone meal to raise the mineral content to about $2.5 \%$ calcium and $0.8 \%$ phosphorus. Starch was added to make up 100 \%. The amino acids were added as a premix in some of the starch. Each time a new batch of basal mix was prepared it was analysed and the formulas of the experimental diets were altered if necessary, so that $6 \frac{1}{2} \%$ protein was always supplied by the basal mix.

Every week records were made of food consumption, of eggs laid by individual birds and egg weights. Live weights of the birds were also recorded at 2 -month intervals.

Since the first experiment showed that similar conclusions were to be drawn from analyses based on either number of eggs or on total weight of eggs laid by each bird, egg numbers were shown in graphs giving an indication of weekly production, and egg weight, which was if anything more sensitive to treatment, in the overall assessments of production. 
The number of bird-weeks lost through culling during the experiments is given in all tables. The weekly egg production shown in Fig. I is for the birds surviving at the end of each week; the total egg production shown in Tables 4,5 and 6 is for the number of starting birds and thus takes into account any effect of diets on mortality and culling.

Table 2. Expt $\mathrm{I}, 1957-8$. Percentage compositions of diets

Basal mix

$\begin{array}{lr}\text { Barley, ground } & \text { ז } 5 \cdot 8 \\ \text { Oats, Sussex-ground } & 12 \cdot 6 \\ \text { Wheat offals } & 12 \cdot 6 \\ \text { Wheat, ground } & 7 \cdot 9 \\ \text { Grass meal } & 4 \cdot 7 \\ \text { Limestone } & 2 \cdot 4 \\ \text { Bone flour } & 0 \cdot 8 \\ \text { Salt } & 0 \cdot 4 \\ \text { Adisco +riboflavin* } & 0.4 \\ & 57 \cdot 6\end{array}$

\begin{tabular}{|c|c|c|c|}
\hline Ingredient & $\begin{array}{c}\text { White-fish meal } \\
\text { diet }\end{array}$ & $\begin{array}{c}\text { Groundnut } \\
\text { diet }\end{array}$ & $\begin{array}{l}\text { Groundnut } \\
+ \text { methionine } \\
\text { diet }\end{array}$ \\
\hline Basal mix & $57 \cdot 6$ & $57 \cdot 6$ & $57 \cdot 6$ \\
\hline White-fish meal & $3 \cdot 7$ & - & - \\
\hline Groundnut meal, GNX 4 & - & $5 \% 7$ & $5 \cdot 7$ \\
\hline Oat feed & $8 \cdot 8$ & $7 \cdot 9$ & $7 \cdot 9$ \\
\hline Bone meal & 3.7 & $4 \cdot 6$ & $4 \cdot 6$ \\
\hline Adisco + riboflavin* & 0.3 & 0.3 & 0.3 \\
\hline DL-methionine & - & 0.0 & $0 \cdot x$ \\
\hline Vitamin $B_{12}$ concentrate $\uparrow$ & - & $1 \cdot 0$ & I. 0 \\
\hline \multirow[t]{2}{*}{ Maize starch } & $25 \cdot 9$ & $22 \cdot 9$ & $22 \cdot 8$ \\
\hline & $100 \cdot 0$ & $100 \cdot 0$ & $100 \cdot 0$ \\
\hline
\end{tabular}

* Commercial preparation containing rooo i.u. vitamin A, 200 i.u. vitamin $\mathrm{D}_{3}$ and $500 \mu \mathrm{g}$ riboflavin per g (Isaac Spencer and Co. Ltd, Aberdeen).

+ Commercial preparation containing $x_{5} \mu \mathrm{g}$ vitamin $B_{12} / g$ (Distillers Co. Ltd, Speke, Liverpool).

\section{Experiment I}

In the first experiment during $1957-8$ the supplementary value of a white-fish meal was compared with that of the poor-quality Burmese groundnut meal $\left(\mathrm{GNX}_{4}\right)$ and of the same groundnut meal fortified with $0.1 \%$ DL-methionine (L. Light \& Co. Ltd, Colnbrook, Bucks.)

The results for egg production are shown in Fig. $1 a$ and Table 3 . Table 3 shows that if the production with a supplement of white-fish meal is taken as 10o, that with groundnut meal would be 83 and with groundnut meal plus $0 \cdot 1 \%$ methionine $9 \mathrm{I}$.

Egg production in the top tier of cages was erratic and low, and information on these birds did not add to that available on the birds in the two lower tiers. Table 4 shows that this tier effect can be attributed largely to a reduction in food intake, presumably caused by position in the house, because for a given food intake there was no appreciable difference in the number of eggs produced. In Expts 2 and 3 only the middle and bottom tiers were used, the top tier being occupied by birds on a commercial diet.

One prominent feature illustrated in Fig. $\mathrm{I} a$ is the way in which peaks and troughs 


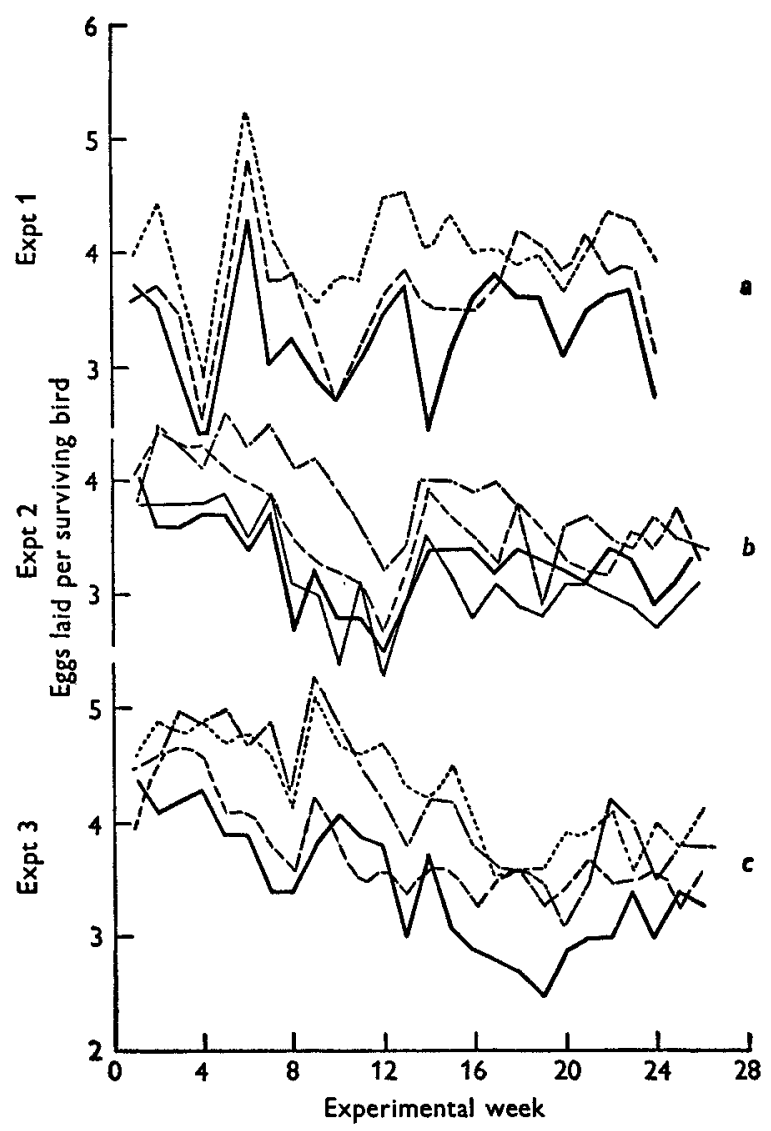

Fig. I. Expts $\mathrm{x}-3$. Effect of various supplements on weekly egg yield. - - . -, white-fish meal; - groundnut meal; ---, groundnut meal plus methionine; -.-.-, groundnut meal plus lysine plus methionine; - - groundnut meal plus lysine.

Table 3. Expt I. Summary of results for the 24 weeks

\begin{tabular}{|c|c|c|c|}
\hline \multicolumn{3}{|c|}{ Type of diet } & \multirow[b]{2}{*}{$\begin{array}{c}\text { SE of } \\
\text { differences }\end{array}$} \\
\hline $\begin{array}{l}\text { White-fish } \\
\text { meal }\end{array}$ & $\begin{array}{c}\text { Groundnut } \\
\text { GNX }_{4}\end{array}$ & $\begin{array}{l}\text { Groundnut } \\
\text { GNX } 4 \\
\text { +methionine }\end{array}$ & \\
\hline 130 & $\mathrm{r} 42$ & 199 & - \\
\hline $2 \cdot 13$ & $2 \cdot 13$ & $2 \cdot 11$ & - \\
\hline+0.09 & to.1I & $+0 . I I$ & - \\
\hline 4.77 & $3 \cdot 8 \mathrm{r}$ & 4.12 & \pm 0.36 \\
\hline $22 \cdot 2$ & $2 \mathrm{I} \cdot 3$ & $2 I \cdot I$ & $\pm \mathrm{I} \cdot 54$ \\
\hline 0.214 & 0.179 & $0 \cdot 196$ & - \\
\hline 4.62 & 3.86 & $4 \cdot 22$ & \pm 0.16 \\
\hline 100 & 83 & $9 r$ & \pm 4 \\
\hline
\end{tabular}

No. of bird-weeks out of 1344 lost through culling

Mean initial body-weight (kg)

Body-weight change during experiment (kg)

Total egg weight/starting bird $(\mathrm{kg})$

Total food eaten/starting bird (kg)

Efficiency (egg weight/food weight)

Egg weight adjusted for equal food intake (kg)

Adjusted egg weight ratios*

\footnotetext{
* The ratio on the diet with white-fish meal taken as 100 .
} 
in egg production occurred at approximately the same time regardless of diet, which suggested that some environmental factor was having an effect on production. Therefore in Expt 2 a continuous record was kept of temperature fluctuations within the laying house.

The results of Expt I suggested that addition of methionine could reduce, by about half, the difference in egg production between birds given supplements of the groundnut meal $\left(\mathrm{GNX}_{4}\right)$ and those given supplements of white-fish meal.

\section{Table 4. Expt $\mathrm{1}$. Total egg production adjusted for differences in food intake}

\begin{tabular}{|c|c|c|c|c|c|c|c|}
\hline \multirow[b]{2}{*}{$\begin{array}{l}\text { Cage } \\
\text { tier }\end{array}$} & \multicolumn{3}{|c|}{ Total weight of eggs/ bird* (kg) } & & \\
\hline & $\begin{array}{l}\text { White-fish } \\
\text { meal diet }\end{array}$ & $\begin{array}{l}\text { Groundnut } \\
\text { GNX } 4 \\
\text { diet }\end{array}$ & $\begin{array}{l}\text { Groundnut } \\
\text { GNX } 4+ \\
\text { methionine } \\
\text { diet }\end{array}$ & $\begin{array}{c}\text { SE of } \\
\text { differences }\end{array}$ & $\begin{array}{c}\text { Mean } \\
\text { egg weight } \\
\text { for tier } \\
(\mathrm{kg})\end{array}$ & $\begin{array}{l}\text { Mean weigh } \\
\text { of food } \\
\text { eaten for } \\
\text { tier } \\
\text { (kg) }\end{array}$ & $\begin{array}{c}\text { Mean } \\
\text { total egg } \\
\text { weight } / \text { bird } \dagger \\
(\mathrm{kg})\end{array}$ \\
\hline Top & $3 \cdot 8$ & $3 \cdot 5$ & 3.9 & \pm 0.23 & 37 & 19.8 & $4 \cdot 1$ \\
\hline Mid & 5.0 & 4.0 & $4 \cdot 3$ & \pm 0.28 & 44 & $22 \cdot 4$ & $4 \cdot 2$ \\
\hline Bottom & 4.9 & $4 \cdot I$ & $4 \cdot 4$ & \pm 0.30 & $4 \cdot 5$ & $22 \cdot 2$ & $4 \cdot 3$ \\
\hline
\end{tabular}

Table 5. Expt 2. Summary of results for the 26 weeks

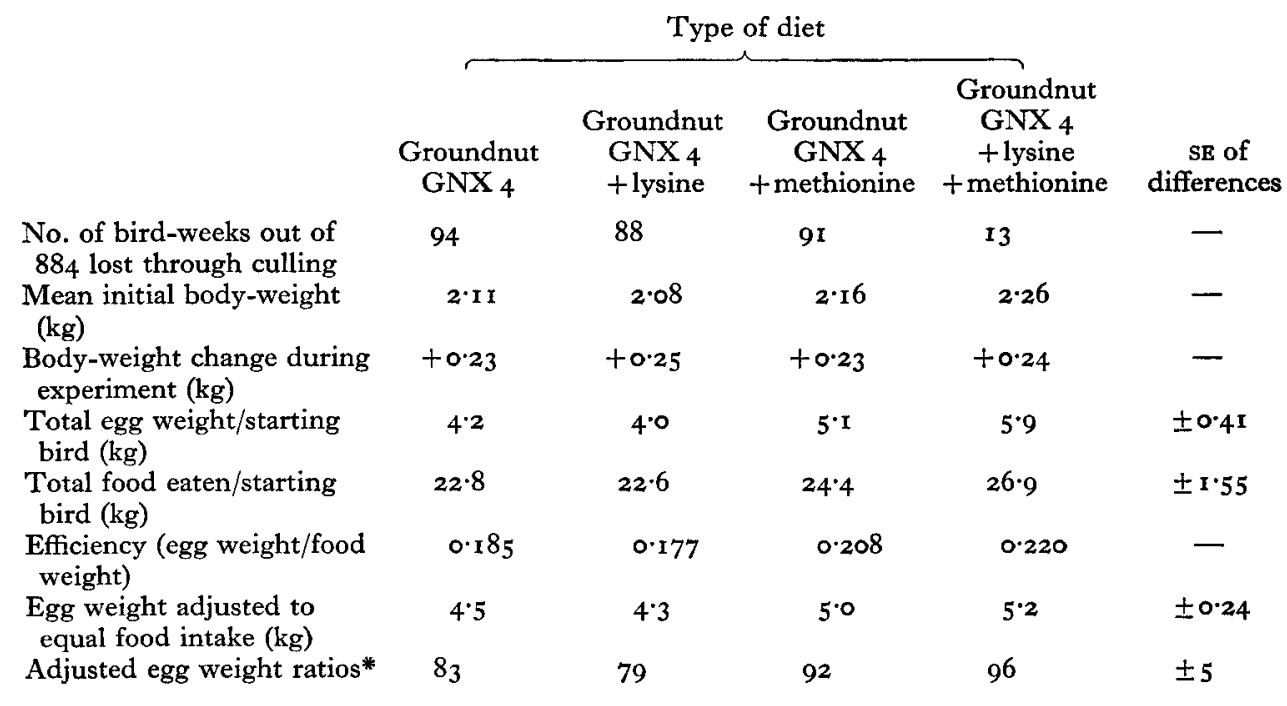

* The ratio on the diet with groundnut meal taken as 83 .

\section{Experiment 2}

As the GPV test is particularly sensitive to the lysine content of the supplementary concentrate (Carpenter, Ellinger, Munro \& Rolfe, 1957) a value as low as 36 for groundnut meal suggests that lysine availability had been affected during processing. In this experiment, therefore, the same groundnut meal was fortified with L-lysine 
(Darvyl L-lysine monohydrochloride, E.I. du Pont de Nemours \& Co. Inc., Delaware, USA), DL-methionine, or L-lysine plus DL-methionine.

A continuous record was kept of temperature within the laying house.

The results are summarized in Fig. I $b$ and Table 5. It can be seen that the addition of lysine alone had no effect on egg production. As in Expt I, addition of methionine alone raised production towards that on the diet supplemented with fish meal. Addition of methionine plus lysine gave yet a further improvement. If the efficiency of egg production on the diet supplemented with groundnut meal alone is taken as 83 , the efficiency with methionine plus lysine in the diet becomes 96. Now in Expt 1, the relative egg productions on the groundnut meal and white-fish meal diets were 83 and 100 (Table 3 ). Thus methionine and lysine added to the groundnut meal increased its value almost to that obtained with white-fish meal. No evidence was found of any relationship between mean, maximum or minimum environmental temperatures and weekly egg production.

Table 6. Expt 3. Summary of results for the 26 weeks

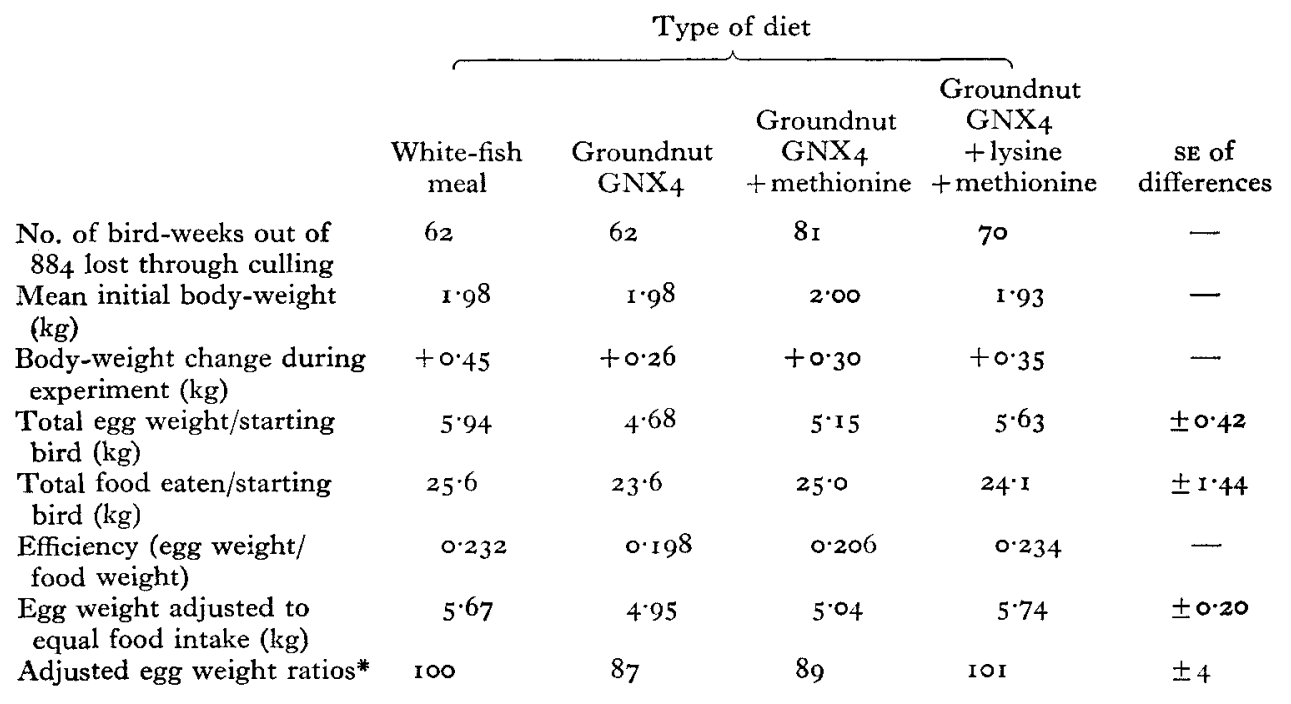

* The ratio on the diet with white-fish meal taken as roo.

\section{Experiment 3}

In the final experiment white-fish meal was compared with the groundnut meal $\left(\mathrm{GNX}_{4}\right)$ alone, the same groundnut meal plus methionine, and the same groundnut meal plus methionine plus lysine. The white-fish meal samples in Expts I and 3 did not come from the same batch but they did come from the same manufacturer, who over a period of 2 years supplied meals of uniform quality as measured by the 'available lysine' test of Carpenter et al. (1957).

The results after 26 weeks are summarized in Fig. $1 c$ and Table 6. There was little difference between egg production with white-fish meal as the supplementary protein source and that with groundnut meal fortified with both methionine and lysine. 


\section{DISCUSSION}

Although white-fish meal protein is superior to groundnut-meal protein for growth when given as a dietary supplement to chicks in early life (Duckworth et al. I96I), the results from our study indicate that it is not necessarily superior when added to diets for egg production. If food-conversion figures may be taken as a criterion, it would appear from the preliminary experiment in this series that a well-processed groundnut meal may provide supplementary protein as satisfactory for egg production as whitefish meal. There is no doubt, however, that the protein quality of groundnut meal cannot be relied upon, especially if the GPV is low. A low GPV generally indicates poor processing at some stage in the preparation of a particular concentrate. It has been shown (Carpenter et al. 1957) that the protein quality of fish meal damaged intentionally by overheating and having a lowered GPV on this account could be partly but not completely restored by addition of lysine. In that study an unusually low GPV was associated with low availability of lysine.

Our study shows that with groundnut meals a low GPV may also indicate a low content or availability of sulphur amino acids. If we may assume that the low value for methionine available in the groundnut meal did not derive from an intrinsically low content in the original groundnut, then it seems likely that poor processing is detrimental to the availability of methionine as well as of lysine. It is possible that several amino acids in the protein molecule may be affected by processing and that we are only made aware of damage to those that are limiting for the production of immediate interest.

The method we finally adopted for comparing protein concentrates is capable of distinguishing differences of the order of $10 \%$ in egg production due to diet and should be suitable for testing the effects of amino acid and other additions to protein concentrates for laying diets.

\section{SUMMARY}

I. In a series of experiments with White Leghorn $\times$ Rhode Island Red hens housed intensively in battery cages, egg production and voluntary feed intake were recorded over a period of 24 or 26 weeks beginning 2 months after the hens came into lay.

2. The diets, which were based on a common cereal mixture, contained supplements of groundnut meal, white-fish meal or groundnut meal plus DL-methionine or L-lysine or both. The protein concentrates under test provided $2 \frac{1}{2} \%$ protein and the rest of the diet, including the cereal mixture with starch, minerals and vitamins, provided about $7 \frac{1}{2} \%$ protein in each diet.

3. Mean egg production was between three and five eggs/bird week depending on the diet. A groundnut meal having the high gross protein value of 54 was not improved as a supplement by addition of DL-methionine but a Burmese groundnut meal having the low gross protein value of 36 was improved.

4. A supplement of white-fish meal in the diet supported production of about $20 \%$ more eggs than a supplement of the poorer groundnut meal. Egg production on this poorer diet was not improved by the addition of $0.1 \%$ L-lysine, but was improved by 
about $10 \%$ when $0.1 \%$ DL-methionine was added, and by about $20 \%$ when both were added, the value of the groundnut meal being thus brought up to that of the white-fish meal.

5. The usefulness of gross protein values in classifying groundnut meals for egg production is discussed.

6. The method used in this work is believed suitable for testing the value of protein in concentrates for egg production.

We wish to thank Dr Gabrielle M. Ellinger for advice on many occasions, Dr A. A. Woodham for determining the gross protein values, $\mathrm{Mr} \mathrm{R}$. B. Williams for analytical assistance and the Misses M. A. W. Jamieson, M. Findlay and F. Tewnion for looking after the birds. We also thank Brown and Forth, Ltd, Manchester, through whom we obtained a gift of the 'Darvyl' L-lysine.

\section{REFERENCES}

Carpenter, K. J. (1954). Proc. World's Poult. Congr. x. Edinburgh, p. 125.

Carpenter, K. J., Duckworth, J. \& Ellinger, G. M. (1954). F. agric. Sci. 44, 340.

Carpenter, K. J., Ellinger, G. M., Munro, M. N. \& Rolfe, E. J. (1957). Brit. F. Nutr. I1, 162.

de Man, T. J. \& Zwiep, N. (1955). Voeding, 16, 147.

Duckworth, J., Woodham, A. A. \& McDonald, I. (r96r). F. Sci. Fd Agric. r2, 407.

National Research Council: Committee on Animal Nutrition (1954). Publ. nat. Res. Coun., Wash., no. 301 .

National Research Council: Committee on Animal Nutrition (1960). Publ. nat. Res. Coun., Wash., no. 827 . 